\title{
About the Secular Growth Trend
}

\author{
Anna Farkas* and Márta Szmodis \\ Department of Health Sciences and Sport Medicine, University of Physical Education, Budapest
}

*Corresponding author: Anna Farkas, Department of Health Sciences and Sport Medicine, University of Physical Education Budapest

\begin{tabular}{|c|c|}
\hline ARTICLE INFO & ABSTRACT \\
\hline Received: 㓞 April 26, 2019 & \multirow{3}{*}{$\begin{array}{l}\text { Secular trend represents a progressive tendency of changes in the consequtive } \\
\text { generations, mostly observed in bodily development and maturation, during growth period } \\
\text { or in adult sizes, and also in functional and psychological variables. The magnitude of the } \\
\text { differences could depend on the genetic traits of the population and the environmental } \\
\text { factors, especially on the level of socio-economical standards. Secular trend changes are } \\
\text { characterized by decades, expressed e.g. in cm for body height, in kg for body weight, or } \\
\text { month for menarcheal age, etc. to compare changes in different populations. }\end{array}$} \\
\hline Published: 㠈 May 03, 2019 & \\
\hline $\begin{array}{l}\text { Citation: Anna Farkas, Márta Szmodis. } \\
\text { About the Secular Growth Trend. Bi- } \\
\text { med J Sci \& Tech Res 17(4)-2019. } \\
\text { 3JSTR. MS.ID.003043. }\end{array}$ & \\
\hline
\end{tabular}

Keywords: Secular trend; Bodily changes; Genetic factors; Environmental conditions

\section{Introduction}

Secular trend is a biological phenomenon in which, the longterm effects of the genetic and environmental factors play roles, by many international publications [1-15]. In the modern societies, from mostly the 1900s, anthropometric measurements showed an increasing tendency of body sizes, especially in adult body height and weight of the population and in the growth and maturation spurt shifted to earlier timing. It is supposed that better nutrition, considering both higher caloric and protein intake, the improving hygienic conditions and other socio-economic factors act on those varied changes. It could also refer to the health status of a population with mostly positive, progressive tendencies of changes [16-18]. Only in a few unfavourable effects could lead to negative consequences, such as wars, famine, worsening of the hygienic conditions, the psychological impacts or even the modern way of living with disadvantageous body changes [19], such as the increasing body fat content, as one of the results of civilizational effects.

In Hungary, the secular trend is thoroughly studied, even since the second half of the nineteenth century we have comparative data on the stature of the recruits $[20,21]$, in university students, and also in athletic and non-athletic samples of youth [13,15,22-24,2534]. Two nationwide studies also showed us the changes of the growth trends $[25,35]$. The anthropometric studies over Hungary demonstrate the regional differences in growth and developmental patterns and in the magnitude of body measurements' trend [3637].
Secular trend could be followed up in the performance level, as well, as stuctural development of the body and the accelerated maturation could help with improving physical capacity [38]. We also have some published $[39,40]$ and unpublished experience about the existence of positive secular trend among Hungarian athletic children e.g. in basketball, where the body height is the key component in the selection. Even in American major league baseball a positive secular trend was observed [41]. However, secular growth changes are supposed come to an end, in a period of time in some of the populations [4,42]. Even in Hungary the trend was varying as the result of the socio-economic changes $[15,18,26]$ but not yet stopped.

In highly civilized societies, e.g. in the Nothern European countries and in Japan, the secular changes are slowing down or levelling off $[14,43]$ or stabilized at a certain body height and in menarcheal age, while in other countries e.g. in Brasil and in Hungary it is yet going on $[15,44]$. There are some further objectives about the secular trend, since we have to understand something concerning the practical use of the knowledge, i.e. when in a younger age child reach a higher level of physical growth and developmental level of the bone system, the balanced growth and the level of coordination could be disturbed. So, they could be exposed to higher incidence of injuries. We have to remember it when planning workload and the evaluation of the performance should be judged by the above-mentioned aspects. At the same time, some further aspects could be arousen, 
e.g. with the earlier biological maturation no paralel changes in the mental, social and psychological maturation would take place. That could have and influence on the pedagogical methodology and the conflict management, as well.

\section{Conclusion}

Secular trend mostly felt as though it would be just a theoretical case to speak and learn more about in respect of the different populations. However, it is a complex phenomenon with multiple causes to be occured, manifested itself mostly in more rapid growth and maturation - characterized by the eralier menarche and the increased size of the body. One of the main reasons is thought to be the better nutrition and the better socio-economical environmental factors. Nevertheless, it could have a significant impact on many other areas of our everyday life.

\section{References}

1. Tanner JM (1966) The secular trend towards on earlier physical maturation. Tijd voor Soc Geneeskunde 44: 524-538.

2. Tanner JM (1981) A history of the study of human growth. Tanner JM (Eds.), University Press Cambridge, New York, USA.

3. Lindgren G (1976) Height, weight and menarche in Swedish urban school-children in relation to socio-economic and regional factors. Ann Hum Biol 3(6): 501-528.

4. Lindgren GW (1991) End of the secular trends in height and maturational rate of Swedish youth? Anthropol Közl 33: 17-22.

5. Lindgren G (1995) Socio-economic background, growth, educational outcome and health. In: Hauspie R, Lindgren G. Faulkner F. (Eds.), Essays on Auxology. Castlehead Publications Ware pp. 408-424.

6. Van Wieringen JC (1978) Secular growth changes. In Faulkner F, Tanner JM (Eds.), Plenum Press New York, London pp. 445-473.

7. Wolanski N (1978) Secular trend in man: Evidence and factors. Coll Antrop 2: 69-86.

8. Susanne C (1985) Living conditions and secular trend. Human Evolution 14(4): 357-370.

9. Fogel RW (1986) Physical growth as a measure of economic well-being of populations: the eighteen and nineteenth centuries. In Faulkner F, Tanner JM (Eds) Human Growth, Plenum Press New York 3: 263-281.

10. Malina RM (1990) Research on secular trends in auxology. Anthropo Anz 48(3): 209-227.

11. Prokopec M (1994) Forty years of monitoring child growth in the Czech Republic: Methodologie, outcomes and comparisons. In: Eiben OG (Eds.), Auxology94. Children and youth at the end of the $20^{\text {th }}$ century. Humanbiologia Budapestinensis 25: 231-240.

12. Jaeger U (1998) Secular trend in Germany. In: Bodzsár ÉB, Susanne C (Eds.), Secular growth changes in Europe. Eötvös University Press Budapest pp. 135-159.

13. Bodzsár ÉB, Susanne C (1998) Secular changes in Europe. In Bodzsár ÉB, Susanne C (Eds.), Eötvös University Press Budapest, Hungary pp: 381.

14. Cole TJ (2003) The secular trend in human physical growth: a biological view. Economics and Human Biology 1(2): 161-168.

15. Bodzsár ÉB, Zsákai A, Mascie Taylor N (2016) Secular Growth and Maturation Changes in Hungary in Relation to Socioeconomic and Demographic Changes. J Biosoc Sci 48, Cambridge University Press 48(2): 158-173.

16. Tanner JM (1986) Growth as a mirror of condition of society. Secular trends and class distinctions. In Demirjian A (Ed) Human Growth - a
Multidisciplinary Review. Taylor and Francis, London - Phyiladelphia 29(1): 3-34.

17. Tanner JM (1992) Growth as a measure of the nutritional and hygienic status of a population. Hormone Research 38: 106-115.

18. Gyenis G, Joubert K (2004) Socioeconomic determinants of anthropometric trends among Hungarian youth, Economics and Human Biology 21(2): 321-333.

19. Photiou A, Anning JH, Mészáros J, Vajda I, Mészáros Z, et al. (2008) Lifestyle, Body Composition, and Physical Fitness Changes in Hungarian School Boys (1975-2005). Research Quarterly for Exercise and Sport 79(2): 168-173.

20. Gyenis G, Joubert K (2000) Secular trend of height in Hungarian recruits. 12th Congress of the European Anthropological Association Cambridge Abstracts pp. 123

21. Gyenis G, Joubert K (2002) Secular trends of body height, body weight and BMI of Hungarian university students and conscripts. Humanbiol Budapest 27: 95-105.

22. Eiben OG (1985) The Körmend Growth Study: Somatotypes. Humanbiologia Budapestinensis 16: 37-52.

23. Gyenis Gy, Till G (1986) Secular changes of body measurements in Hungarian university students between 1976-1985. Anthrop Közl 30: 147-150.

24. Bodzsár ÉB, Pápai J (1994) Secular trend in body proportions and composition. In: Eiben OG (Eds.), Auxology 94. Children and youth at the end of the $20^{\text {th }}$ century. Humanbiologia Budapestinensis 25: 245-254.

25. Eiben OG (1989) Secular trend in Hungary. Humanbiol Budapest 19: 161-168.

26. Farkas A, Mészáros J, Mohácsi J (1991) A study on the secular trend in young adults. Antropológiai Közlemények 33: 171-176.

27. Mohácsi J, Mészáros J, Farkas A (1994) Secular growth trend in height, body weight and growth type indices of boys aged between 14 to 18 . In: Eiben OG (Eds.), Auxology 94. Children and youth at the end of the $20^{\text {th }}$ century. Humanbiol Budapest 25: 369-372.

28. A Farkas, R Frenkl (1997) Secular trend changes in Hungarian schoolboys. In N Armstrong, B Kirby and J Welsman (Eds.), Children and Exercise XIX. E and FN Spon London Weinheim New York Tokyo Melbourne Madras pp: 81-87.

29. Németh Á, Eiben OG (1997) Secular growth changes in Budapest in the $20^{\text {th }}$ century. Acta Medica Auxologica (Milano) 29: 5-12.

30. Gyenis Gy (1997) Continuing positive growth changes in height and weight of Hungarian university students. Annals of Human Biology 24(5): 475-479.

31. Othman M, Mészáros J, Szabó T (2002) Secular trend and motor performance in Hungarian schoolboys. Kinesiology 34: 127-133.

32. Bodzsár ÉB, Zsákai A (2002) Some Aspects of Secular Changes in Hungary over the Twentieth Century. Coll Antropol 26(2): 477-484.

33. Bodzsár ÉB, Zsákai A (2007) Present state of secular trend in Hungary. In: Bodzsár ÉB, Zsákai A (Eds.), New Perspectives and Problems in Anthropology. Cambridge Scholars Publishing Newcastle pp: 217-227.

34. Bodzsár ÉB, Zsákai A (2009) Secular growth changes in the growth pattern of Budapest children. Anthropológiai Közlemények 50: 49-60.

35. Tóth G, Suskovics CS, Buda B (2009) The Körmend Growth Study 2008 (in Hungarian). Folia Anthrop 8: 67-70.

36. Suskovics Csilla, Nagyváradi Katalin, Kocsis Csabáné, Némethné Tóth Orsolya, Bíróné Ilics Katalin, et al. (2015) Kaposvár Growth Study: secular changes int he bodies measurements of the 10 to 15 years-old children (In Hungarian). Folia Anthropologica 14: 93-102.

37. Malina MR (2004) Secular trends in growth, maturation and physical performance: a review. Anthropol Rev 67: 3-31. 
38. Szabó T, Pápai J (1997) Physical and motor structure characteristics of 11 to 17 year old. In Armstrong N, Kirby BJ, and Welsman JR (Eds.) Children and exercise XIX. Promoting health and well-being. E and FN SPON London Weinheim New York Tokyo Melbourne Madras pp: 99 104.

39. A Farkas, G Ag, M Szmodis (2011) Are the any detectable secular growth changes in young male athletes? In: Craig A, Williams, Neil Armstrong (Eds.), Children and Exercise XXVII, The Proceedings of the XXVII ${ }^{\text {th }}$ International Symposium of the European Group of Pediatric Work Physiology Chapter No 46. Routledge, Taylor \& Francis Group London and New York, USA, pp. 305-308.

40. Saint Onge Jarron M, Krueger Patrick M, Rogers Richard G (2008) Historical trends in height, weight, and body mass: Data from U.S. Major

\section{ISSN: 2574-1241}

DOI: 10.26717/BJSTR.2019.17.003043

Anna Farkas. Biomed J Sci \& Tech Res

(C) This work is licensed under Creative

Submission Link: https://biomedres.us/submit-manuscript.php
League Baseball players,1869-1983. Economics \& Human Biology 6(3): 482-488.

41. Vercauteren M, Susanne C (1985) The secular trend of height and menarche in Belgium Are there any signs of a future stop? European Journal of Pediatrics 144(4): 306-309.

42. Kurokawa N, Nakai K, Suzuki K, Sakurai K, Shimada M, et al. (2008) Trends in growth status among schoolchildren in Sendai, Japan, 19942003: leveling-off of mean body height and weight. Tohoku J Exp Med 216(4): 371-375

43. Vargas, Deisi Maria, Arena, Soncini, Ana Silveira, et al. (2010) The secular trend of growth in height in Blumenau, Brazil, and its relationship with the human development index (HDI) Rev Assoc Med Bras 56(3): 304308.

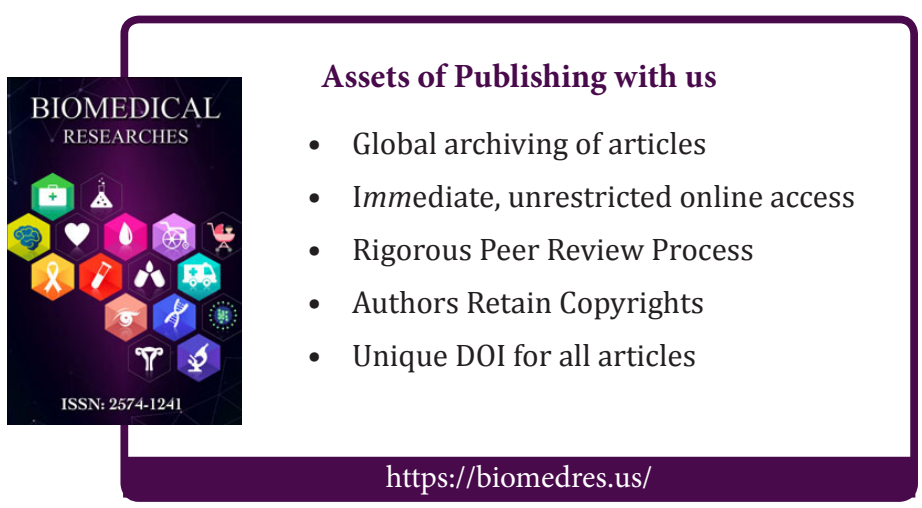

